PARLOUR GAMES AND THE PUBLIC LIFE OF WOMEN IN RENAISSANCE ITALY 
This page intentionally left blank 
GEORGE McCLURE

\section{Parlour Games and the Public Life of Women in Renaissance Italy}


(C) University of Toronto Press 2013

Toronto Buffalo London

www.utppublishing.com

Printed in Canada

ISBN 978-1-4426-4659-9

(\$)

Printed on acid-free, $100 \%$ post-consumer recycled paper with vegetablebased inks.

\section{Library and Archives Canada Cataloguing in Publication}

McClure, George W., 1951-

Parlour games and the public life of women in Renaissance

Italy / George McClure.

Includes bibliographical references and index.

ISBN 978-1-4426-4659-9

1. Women - Italy - Social life and customs - 16th century.

2. Women - Italy - Intellectual life - 16th century. 3. Women Italy - History - Renaissance, 1450-1600. 4. Indoor games - Social aspects - Italy - History - 16th century. 5. Renaissance - Italy.

6. Italy - Social life and customs - 16th century. I. Title.

HQ1149.18M34 $2013 \quad 305.4094509$ '031 C2012-908140-X

University of Toronto Press acknowledges the financial assistance to its publishing program of the Canada Council for the Arts and the Ontario Arts Council.

Canada Council Conseil des Arts for the Arts du Canada

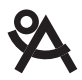

ONTARIO ARTS COUNCIL CONSEIL DES ARTS DE L'ONTARIO

50 YEARS OF ONTARIO GOVERNMENT SUPPORT OF THE ARTS 50 ANS DE SOUTIEN DU GOUVERNEMENT DE L'ONTARIO AUX ARTS

University of Toronto Press acknowledges the financial support of the Government of Canada through the Canada Book Fund for its publishing activities. 